\title{
The Influence of L2 English Acquisition of the Request Speech Act on Persian Preschool Children
}

Firooz Sadighi, Shahrzad Chahardahcherik*, Maryam Delfariyan, Fariba Feyzbar

Department of English Language, Shiraz Branch, Islamic Azad University, Shiraz, Iran

Corresponding author: Shahrzad Chahardahcherik, E-mail: Ch.shahrzad@gmail.com

\begin{tabular}{l} 
ARTICLE INFO \\
\hline Article history \\
Received: July 26, 2018 \\
Accepted: September 04, 2018 \\
Published: October 31, 2018 \\
Volume: $6 \quad$ Issue: 4
\end{tabular}

Conflicts of interest: None Funding: None

\begin{abstract}
In Iran the age of learning English as a foreign language is decreasing yearly. It is obvious that learning English at a very early age is a most appropriate time to start. The investigation in this study is focused on the speech act of request. Instructional effects of learning request strategies are assessed in preschoolers who received instruction to find out whether the exposure to the foreign language learning enhances the development of request strategy use and brings about changes in their first language strategy use features. The data were collected from 10 preschool Iranian learners of English as a foreign language. The participants of the study took a twosemester speaking course in an academic setting in Iran. The study had a pretest and posttest design in which 10 conversations were used including polite request strategies of English to analyze instructional effects on the learners' first language after the posttest, by comparing and measuring the backward transfer against the pretest results. The oral task was in the form of role plays which were also utilized for communicative practice with the learners. The data were rated for the extent of a foreign language effect on the first language by experienced tutors and linguistic analyses were done to identify the foreign language components of request strategies features in the first language production. Results showed that frequent use of English request strategy features in the first language was an indication of L2 students' beneficial experience in their L1.
\end{abstract}

Key words: Pragmatic Competence، L2 Learning, Preschoolers, Back Transfern, Speech Acts

\section{INTRODUCTION}

Language development has a vital role in the child's overall development. Language development is responsible for supporting the child's ability in communicating, expressing understanding feelings as well as thinking and problem-solving, and developing and keeping relationships in an acceptable condition. An important and first step in literacy, and also a fundamental one for learning to read and write is learning to understand, use and enjoy language. Language or grammar accuracy is considered to be the same as a second language or a foreign language (FL) for many years. However, with the advent of communication methods, such as Communicative Language Teaching (CLT), this view is replaced by new point of view. The focus is on achieving functional abilities in the target language. The ultimate goal is to understand and produce a language suitable for communication by applying specific social and cultural parameters for this purpose. Failure to succeed can lead to misunderstandings and, in most cases, disruption of communication and insensitivity to ambiguous or inappropriate stereotypes of TL learners (Thomas, 1983). However, you may find that there is no guarantee that learners can use these resources at the same time. In this regard, Blum-Kulka (1991) empha- sizes that learners' limited second language (L2) knowledge or problems to acquire it is an important obstacle for learners to use their general pragmatic knowledge base. Bialystok (1993) claims that adult L2 or foreign language (FL) learners need to develop new pragmatic and social pragmatic knowledge that does not exist in their L1 to gain control over their existing pragmatic basis. This includes contact for pragmatic realization, discussion of underlying communicative behavior of metapragmatic knowledge and instructions for interactive activities, in which learners can practice to use the acquired language knowledge, which can help solve these problems. In addition, the investigation focuses on the implementation of speech actions by foreign learners (Bardovi-Harlig, 2001; Olshtain \& Blum-Kulka, 1985; Yang, 2009). It emphasizes the importance of pragmatic education supported by the performance report. A large amount of grammar skills does not always represent a successful pragmatic representation in the target language (TL). In addition, Schmidt (1993) advocates teaching. He assumes that caregivers can use certain strategies to teach communication practices of social groups, which are very effective for the pragmatic development of L1 children. Adult L2 learners without a formal learning background usually do not receive 
adequate feedback and, in some cases, do not have the relevant input to help teach L2 pragmatics. Learners need pragmatic guidance and provide language tools that enable them to recognize and understand language behavior in a contextual way. These findings have heightened our understanding of early childhood language development and developmental development. In addition, we become increasingly aware of the role of dialogue (e.g., parent-child or caregiver/teacher dialogue). In addition, we understand better how contextualized languages can play a part in language development and how to enhance language development in preschool children and babies. Most importantly, structured drama is considered as effective in the development of language skills.

A brief overview of the literature on communicative skills shows that pragmatic competence has not been fully studied in comparison to other components of language communication skills. Lack of sufficient research is prominent in research and material development (Salazar, 2003). According to previous studies, the development of pragmatic and grammatical abilities is not linked to second language learners. Students with good grammar and word meaning do not have the necessary functional or functional information to properly communicate their expected information in the proper communication settings (Eslami-Rasekh \& Abdolnazarpour, 2010; Yu, 2011). Therefore, it can be deduced that pragmatics education should be an indispensable element of the language of instruction. Children in school need to learn basic language and communication skills urgently to be successful. The ability to use words, gestures or facial expressions to understand others (i.e., language) and express themselves (e.g., Expressive Language) is within the range of language and communication skills. Children with high skills in language and communication are more likely to study at school. In addition, they have less difficulty reading and have greater achievements in school. Children's brain is fast in the early years of life. Develop the foundation and foundation for the foundation of learning. Children's interactions with adults play a key role in children's development and learning styles. Therefore, pre-school teachers must provide children with an interaction that helps them grow and develop, especially their language and communication skills. As previous studies have shown, children will develop language skills if they provide a higher level of language stimulation in their early years of life. One study has shown that one third of teacher-language language interactions often promote children's language development. The other two thirds consist of less complex language, including directions, general praise and rhetorical questions. High quality children - Adult interaction can enrich the student's experience and pave the way for the language and communication growth of children. The findings confirm that the interaction between adults and children is important for young children. Interactions compass responding to children's vocalizations and speech, involving in joint attention with children, eliciting conversations with children, talking with children more, applying complex grammar and rich vocabulary, raising the children's awareness of objects, emotions, or events. The activities in this guide can easily be practiced with any child. There is a view that the child's development takes place at different speeds and in different ways. In this regard many factors are valid for both personality and age. In addition to these factors, exposure to family language can influence the development of children's language and communication skills. By applying these practices, early childhood educators will provide numerous language contracts and opportunities for all children who need to improve their language and communication skills.

\section{OBJECTIVE AND RESEARCH QUESTIONS}

The purpose of this study was to test the impact of the second language on the first language by investigating the impact of English request strategy knowledge on the use of Persian request strategies. We try to find out whether ESL students have a backward shift from English to Persian from the pragmatic and discourse levels.

This study aims at answering these two research questions:

1. Do learning second language request features affect mother tongue use of request strategies?

2. Does pragmatic transfer occur in the request act of Persian L2 learners of English in terms of the frequency of foreign language request act features?

\section{LITERATURE REVIEW}

According to Albirini and Benmamoun (2014), an integral part of second language acquisition research is language transfer. It is noteworthy that the transfer is two-way, i.e., there is an interaction between the two languages. It is a two-way street. The first language can affect the second language, while the second language can affect the first language. The former (the first language effect in the second language) is called a forward transfer, and the latter is called a reverse transaction. Long-term transfer has long been an attractive area for in-depth research by linguists and researchers. They studied this phenomenon from different perspectives, such as comparative analysis, cross-language influence, and parameter reset, to name a few. However, research on back transactions is far widespread. Laufer, Pavlenko and others carried out related research in a versatile environment (Cook, 2003). In addition, some Chinese scholars have focused their attention on the deterioration and made insightful observations. Zhang and Wang et al (1997) studied the impact of English on Chinese. For this reason, they examined two "poorly translated sentences" and called them the second language effect on direct translation; Zhang (1995) used the nominal structure other than IP as an example to demonstrate the effect of the second language in the first language. Kesckes and Papp (2000) studied the English features of four spoken English-speaking English. So far, few studies involved the effect of the second language on the first language causative clause. Perhaps many researchers did not notice the difference between English and Chinese causal terms.

There are at least three ways that the second language can impose effects on the first language. Firstly, it boosts the first language use. Secondly, it damages or impairs the 
first language use. Thirdly, it is neutral and keeps the first language use intact. We can state that the second language users are considered to be a special group of language users. They have a different kind of knowledge of the second language compared to the native speakers. Similarly, their first language knowledge is different from that of the monolingual speakers. As Cook (2003) puts it, they have a different mind from those of the monolingual speakers. Thus, it seems sensible to conclude that ESL students have different minds both from English native speakers and Chinese monolingual speakers, for example. There are two languages that interact and affect each other in their minds. Consequently, the two linguistic systems affect each other reciprocally. According to Gass and Selinker (2008) Language learning development in children encompasses the following stages: By 24 months of age children are expected to understand single words referring to objects that are out of sight. They are able to respond to yes/no questions and listen to simple stories. Their vocabulary repertoire includes an average of 200 to 300 words. The vocabulary storage is made up of nouns (teddy, car) and verbs (push, jump) that allow them to combine words to form simple statements (push car). As with the exploration of pragmatics as described by Kasper (2002), we can find various definitions that explain the pragmatic concepts in the field. Morris (1998, as cited in Liu, 2007) introduced the first realistic pragmatic definition. Since then, many other experts in the linguistic branch have further conceptualized the concept. Morris (1998) first defined pragmatics as "studying the relationship between symbols and interpreters, while semantics explores the relationship between symbols and the objects on which symbols are applied" (as described in Liu, 2007). Kaspar (1993) defined this term as "studying people's understanding and production of language behavior in context" (p.3). This concise definition refers to the context and elements of production as the relevant elements of pragmatics and the basis of any speech action in the language. According to Kaspar (1993), the context includes the social and cultural environment of communication. These situations have a major impact on the formation, receiving and receiving of messages. In addition, Kasper uses a broad term "language behavior" (p. 3), which is a generic term used to describe learners' ability to discourse. It is worth mentioning that emphasis is also placed on understanding and production. This distinction usually relates to the daily life of second language learners. As far as these definitions of pragmatics are concerned, there is another important aspect to be discussed, namely pragmatic competence. The learner understands, builds and communicates the meaning of accuracy and applicability in the social and cultural environment of communication. For second language learners, this is the goal, and as described elsewhere, it is a very difficult task. According to Barron (2003) pragmatic competence is an element of communicative skill. Barron believes that pragmatic competence is part of the linguistic abilities of a combination of language and verbal functions as well as the proper use of language in context. Some sociolinguists have solved these problems.

Hymes (1974) suggested a model diagram of the mnemonic device S-P-E-A-K-I-N-G to show the main components.
$S$ stands for setup and scene, the social and physical state of communication. It also includes time of day. $P$ stands for participants, people involved in communication, and their roles and relationships. $E$ stands for the purpose, the purpose of the communication or the expected outcome. $A$ describes action verbs, exchanges or different parts of the entire communication. $K$ stands for key, tone or swap. I stands for instrumentalities. $N$ stands for norm, a social waiting or rule that pulls or communicates communication, and is open. $G$ stands for genre, i.e., The Act of Speaking or Communication. Dewey (2007) made a simple but insightful comment that this experience is not a source of learning, but a reflection of this experience. As Dewey emphasized, the reflection of human experience is crucial to the study of pragmatism, a model derived from Dewey's concept by David Kolb (1984). Accurate introduction to the subject: This phase is characterized by an accurate introduction to the topic and involves a unique presentation of speech works and an analysis of practical aspects. As stated by the rules, this expression must be expressed in clear and clear terms rather than exaggerated. To achieve this goal, current needs (communication and utility) are presented with a supportive language that is familiar and understandable to learners. Students are expected to obtain successful and proper communication through the appropriate use of practical elements. Presenting a speech with a real presentation of the situation will be of great help to the presentation. In this process, students understand the practical aspects of miscommunication and see them through a theme. Exercise: At this stage the focus is on practice. Students will participate in a series of activities designed to integrate the target-pragmatic elements and improve their fluency. Some activities may include short conversations or conversations in conversations. Dialogues are especially effective because they depict specific cultural contexts. All activities have a pragmatic component. The role play situation can then be performed in the extended group, or the whole class will participate in the activity. This activity is very effective for students to master pragmatic skills. Searle (1976) provides a complete classification of involuntary behavior, including six types:

1. Representative: Describe the state of affairs (recognition, statement, assertion, etc.);

2. Assignment: Let someone do something (request, ban, warning, order, etc.);

3. Question: Let someone provide information (queries, queries, etc.);

4. Commissive: Let the speaker do something (dedication, vows, promises, etc.);

5. Expression: Express the emotional state of the speaker (excuse, thank you, congratulations); and

6. Statement: Change the status of an entity (name, appointment, resignation, etc.).

Ellis (1994) gives a definition of a request as a speaker trying to allow the listener to stop or stop conducting a certain behavior (p.167). According to Searle's (1969) classification of involuntary behavior, the request belongs to the teaching category and is defined as "the act of allowing the listener to act as a speaker's desired behavior and the listener will not be 
under normal circumstances do not. "(page 66). According to Brown and Levinson (1987), the request is classified as an FTA because the speaker will be charged to the audience. They point out that when people want to make a free trade agreement, they can try to moderate their impact on the listener's face. Speakers choose different strategies based on the seriousness or importance of free trade agreements. The degree of compulsion, the relative power of the listener and the social distance between the speaker and the listener are variables that the speaker considers. As Yule (1996) said, it is important that speakers use proper forms of requests; otherwise, it may sound rude, which might cause communication problems. Brown and Levinson (1987) and Leech (1983) stated that direct requests are regarded as rude because they restrict the listener's freedom of expression, and indirectly, the strategy the speaker uses to increase authorization. Cook (2003, p. 2) introduces the concept of "multiple abilities", "a kind of knowledge of two or more languages in the mind." The study of multiple abilities is to figure out how two or more languages work in the mind of the speaker. These two languages are not completely separated or fully assimilated, but form an integrated continuum. The integrated continuum does not necessarily apply to the entire language system. It does not necessarily influence individuals in the same way. The integrated system can also be linked to different stages of second language development (Cook, 2003). The second language can influence the first language in at least three ways: it increases the use of the first language. This may impair the use of the first language or remain neutral to the use of the first language. Second language users are special since their knowledge of the second language differs from that of native speakers. Their knowledge of the first language differs in some respects from that of monolinguals (Cook, 2003).

Language transfer is a crucial element of research in second language acquisition. The transfer is two-way: the first language can have an impact on the second language and the second language may also have an impact on the first language. The first is called forward transfer and the latter is called backward transfer. In this area, Laufer, Pavlenko and others have conducted research (see Cook, 2003). In China, some scholars also discussed the backward displacement. Among them, Keskes and Papp (2000) studied English influence in Chinese by examining two "wrong translation sentences" and calling them second-language effects in direct translation. Zhang (1995) demonstrated the existence of first language impact in the first language using a different nominal structure from Zhang (1995) investigated the English features of four spoken English speakers. However, there is very little research on the impact of the second language on the first language causative clauses. Perhaps researchers have failed to notice the difference between English and Chinese causal terms. Therefore, this study aims to demonstrate the existence of a backward shift by studying the impact of English causality on Chinese causality. The pragmatic transfer has received considerable attention. Olshtain and Cohen (1990) refer to pragmatic conversion as a strategy for L2 learners to combine mother tongue-based elements in L2 production. Pragmatic transmission is an important source of cross-cultural communication collapse (e.g., Beebe, Takahashi, \& Uliss-Weltz,
1990). A good example of pragmatic language transmission is provided by Takahashi and DuFon (1989), who investigated the use of indirectness by nine Japanese-English ESL learners in two tempting contexts. They found that primary skill L2 learners in either case were also too direct or indirect when they chose indirectly. In another case, Byon (2004) identified the social pragmatic features of Americans who learn Korean as a foreign language in Korean communication requests. Regarding pragmatic portability, Takahashi $(1993,1996)$ claims that this strategy will be more likely to shift to the L 2 context if the L1 strategy is often used and considered appropriate. Her second transferability criterion, the equivalence of the strategies in L1 and L2, is considered equivalent to the L1 and L2 pairs of the request strategy in terms of contextual suitability. Based on the above-mentioned two criteria, she presents a pragmatic portability scale that is considered easier to move to strategies with higher contextual suitability degrees and strategies that are considered contextual equivalents, and those designated. Strategies that are less sexual and considered. Being contextually different is less transferable. This study aims to explain the problem of pragmatic portability by investigating the portability of Persian rejection strategies when Persian learners reach English rejection in the corresponding L2 context.

Dialogue through a variety of speech acts is defined as doing things through the language, including queries, thanks, excuses, commands, promises, requests, warnings, threats, etc. (Austin, 1962; Searle, 1969). The speech act of requests that if the focus of this study often come from at least two or more people and have an illocutionary meaning. Because the request is essentially a threatening act, the speaker is concerned with the maintenance of face, which is a sense of language and social identity. Therefore, speakers use a variety of face-to-face strategies (Brown and Levinson, 1987). As suggested by Goffman (2006), this request creates a good opportunity to study the differences in production because individuals need to remember different factors like power, distance and audience to reach the desired object. In addition, there may be differences between cultures when these considerations are implemented. For example, in their project entitled Cross-Cultural Speech Act Realization Project (CCSARP), Blum-Kulka and Olshtain (1984) examined cultural and linguistic specific requests and differences in eight cultures and language excuses. They believe that every society has a polite approach, but some cultural concepts can interfere with the uniqueness of courtesy and influence the concept of social courtesy. Speakers in some languages prefer to use speech acts in different ways. For example, requests and apologies are used more directly in Hebrew and Russian (Blum-Kulka \& Olshtain, 1984), such as requests and complaints in German (Kasper, 1993) and Japanese (Fukushima, 2002). the same. Children have long recognized the quality of language in the social environment before they are fully qualified for language production. Since children are highly dependent on caregivers to meet their physical and psychological needs from the age of one, reflexive vocalization has become a prerequisite for mature forms, and progressive development has great interest in the development of children's legal rights. 
First, we will emphasize the prominence of early language learning for the age of the child. Every normal child has 100 billion brain cells at birth, and each brain cell has a total of 20,000 connection points. Whether these brain cells are linked or killed depends on whether the child lives in a fulfilling environment (Buzan, 1984; Diamond, 1988; Ornstein, 1984). The ability of young children is to take knowledge as part of the natural process. When they are immersed in the language, they can learn quickly and easily while playing. Therefore, the key to fast and effective language learning is to become more like a child. If you touch at least 2000 words, teach the children in a comprehensive environment. An important year for children to learn naturally is preschool children. At that stage, there is no difference in learning a first language or a second language. In the third year of life, define the basis of thinking, language, vision, attitude, talent and other characteristics (Yarmohammadi, L. 1995). In the early days of life, children formed primary education in the brain (Bloom, 1964). The brain has six main roads, including vision, vowel, taste, touch, smell and behavioral learning (Dryden \& Vos, 1997). All the information we use later is gathered in the early stages of development. Half of ordinary children are under 10 years old. Five billion will last a lifetime. Foreign language teaching should start when the child is in kindergarten, and the teacher can maximize the child's willingness and ability to learn.

\section{Direct Level}

1. Mood derivable: Statements in which the grammatical mood of the verb indicates illocutionary force. (For instance, sit on your chair)

2. Performative: Statements in which the illocutionary force is expressed in an explicit way. (For instance, I tell you sit on your chair)

3. Hedged performative: Statements in which identification of the illocutionary force is adjusted by hedging expressions. (For instance, I would like to ask you to leave)

4. Obligation statements: Statements that express the responsibility of the hearer to perform the act (for instance, Sir, you'll have to take off your shoes before you enter the house). 5 . Want statements: Utterances which express the speaker's desire that the hearer performs the act (for instance, I want you to take off your shoes before you enter the house).

\section{Conventionally Indirect Level}

1. Suggestory formulae: Utterances in which there is a suggestion to do something (for instance, (How about playing chess?).

2. Query-preparatory: Statements which include a reference to preparatory conditions (e.g., ability, willingness) as conventionalized in any specific language (for instance, would you mind opening the window?).

\section{Non-conventionally Indirect Level}

1. Strong hints: Statements in which there is a partial reference to an object or element required for the implementation of the act (for instance, playing card is boring).
2. Mild hints: Statements which make no reference to the request proper (or any of its elements) but are interpretable as requests by context (for example, we've been watching this movie for more than one hour).

\section{METHODS}

A quantitative approach to research has been selected to collect the information to answer the research questions and determine whether a reverse language transfer occurs in an Iranian EFL setting. Given the time limit, just ten participants were selected to take part in the experiment. A test including 10 requests was given at the beginning and the end of the program. The teacher instructed the L2 learners to perform the same role play in their L1, Persian. L1 responses were also collected from 12 Persian speakers. L1 responses to all items in pre- and post-tests were analyzed. For overall gains, two teachers independently compared each participant's pre- and post-test responses and rated the improvements. The researcher analyzed the situation by observing and collecting evidence of pragmatic transfer as it occurred in natural discourse in classroom. The conversations were comprised of situations; each situation had two possible responses; one was based on pragmatic transfer from English to Persian, the other is a native utterance that has no pragmatic transfer, to find out the participants' most appropriate act in the situation described.

\section{Participants}

To ensure as much equivalence as possible in the subject sample, Iranian undergraduate students enrolled in a language institute in Shiraz, were selected as the target population. The fact that these subjects were preschool children makes the sample homogeneous in terms of the members' educational background and assumed literacy level in their native language.

\section{Research Instrument and Procedure}

One group of the participants took 4-mounth L2 English course; the participants were given English proficiency lessons in which request strategy skill were taught. The sample chosen for this study was deliberately selected randomly from Persian-speaking EFL preschoolers. These students, who were at elementary level of EFL, range in age from 5-6. The study was conducted with 10 preschoolers native Persian-speaking who were at the same L1 proficiency level. The group of learners took two- semester-EFL speaking course. The request strategies in the following classification are ordered according to decreasing degree of directness (Blum-Kulka House, and Kasper, 1989).

\section{Research Design}

The present study examines the relationship between English language learners' L2-L1 pragmatic skills transfer and the effect of L 2 conversation courses on request strategy use 
skills in L1. Furthermore, it is questioned that whether there are any positive changes that might occur in L1 request acts skills. The participants are chosen based on convenience.

\section{Research Setting, Instruments and Procedure}

Data for the study were collected at the end of the winter and spring semesters after the group of students completed their L2 speaking courses. The data were gathered through observing and interviewing Iranian preschool English as foreign language learners. The requestive utterances that appeared in children's utterances were recorded and transcribed. The classification proposed by Blum-Kulka and Olshtain (1984) in CCSARP was applied. In this model, twelve segments are recognized for English language request utterances. The produced utterances were tape-recorded, transcribed, and submitted to a qualitative analysis. They were scrutinized on the use of Persian language request strategy tools (openers, softener, understatement, downtowner, intensifier, filler, appealer, attention-getter, preparatory, grounder, expander, please) and English language features (imperative, performative, implicit performative, obligation statement, want statement, preparatory questions, suggestion, permission, mitigated preparatory, non-conventionals). The teaching program reported in this paper was of two semester duration. One week prior to the pre-test, and in accordance with the

Table 1. Frequency of strategies by all students before and after education (10 subjects)

\begin{tabular}{lcc}
\hline Feature (L 1) & Pre-test & Post-test \\
\hline Understand & 10 & 0 \\
Downtowner & 8 & 0 \\
Intensifier & 8 & 0 \\
Appealer & 10 & 0 \\
Preparatory & 0 & 7 \\
Grounder & 3 & 5 \\
Expander & 2 & 8 \\
Please & 9 & 10 \\
\hline
\end{tabular}

requirements of the institute's ethics committee, the students and their parents were provided with information about the study and were given the opportunity to ask questions before signing a consent form. In the first hour of the program, a conversational interview was conducted. It included...?

Two types of language data were collected from two groups of participants; (1) English request strategies by 10 Persian learners (2) Persian request strategies by 10 Persian learners of English.

\section{Data Analysis}

This part deals with the distribution of request strategies used by native Persian speakers as EFL learners as mentioned in their interviews as pre-test and post-test. To this end, the requests uttered according to Persian and English request features were transcribed and categorized according to Olshtain and Blum-Kulka's (1985) model of directness and politeness levels. In order to answer the research questions, a parametric data analysis was conducted for each language group. The frequencies obtained for each choice of Persian request features as pretest were tallied and recorded in Table 1.

As we can see, based on the Table 1, the average frequency of English words pronounced by students before and after training was obtained, which is statistically significant indicating the effect of the treatment. Table 2 shows the frequency of strategies used by the 10 students before and after the treatment (10 subjects).

A paired-samples $t$-test was conducted to find out whether learning language request features affects mother tongue use of request strategies or not. According to Table 3, there was a statistically significant difference between the pretest score and the posttest score $(p=.006)$.

Therefore, we can conclude that the acquisition of English language request features affects the use of Persian request strategies as the first language.

The second research question investigated whether pragmatic transfer occurs in the request act of Persian L2 learners of English in terms of the frequency of foreign language request act features. In order to answer this question, a paired-sample t-test was conducted.

Table 2. Frequency of strategies used by students $(n=10)$

\begin{tabular}{llcc}
\hline Feature (L 2) & & Pre-test & Post-test \\
\hline Direct & Imperative: please ... & 10 & 10 \\
& Per formative: I'm asking you to & 2 & 0 \\
& Implicit per formative: I want to ask to ... & 0 & 5 \\
& Obligation statement: you should & 0 & 1 \\
& Want statement: I want you to ... & 0 & 0 \\
Indirect & Preparatory questions: could you... & 0 & 9 \\
& Suggestions: How about ... & 5 & 1 \\
& Permissions: May I ... & 0 & 7 \\
& Mitigated preparatory: I'm wondering if you could ... & 0 & 5 \\
& Mitigated wants: I'd appreciate it if you could... & 0 & 6 \\
& Non-conventional indirect strong hint: my pen just quit. I need a pen. & 0 & 1 \\
\hline
\end{tabular}


According to Table 4, there was a statistically significant difference between the pretest scores and the posttest scores. Therefore, we can conclude that pragmatic transfer occurred in the request act of Persian L2 learners of English in terms of the frequency of foreign language request act features.

\section{DISCUSSION}

This paper examines the effect of long-term L2 exposure on the L1 grammar. More specifically, it tries to understand whether and to what extent the psychological representation of L1 is changed under the influence of $\mathrm{L} 2$. The impact of non-native languages on L1 may be positive (e.g., RicherL1 semantics and grammar), negative (e.g., L1 lost or loss during LR presentation, L2 accent) or neutral (see Cook 2003 for details). It can detect the effect on L1 in early or late stages of learning, depending on the level of language being investigated and the later perceived effects at higher levels (Kecskes, 2008). At lower levels of vocabulary and speech processing, the impact of L2 on L1 is already identifiable after a period of immersion in the L2 language field. For example, after immersion in the L2 country for 4 months, the nominal delay of low-frequency L1 words is slower, due to the lower frequency of L1 used during L2 immersion (Linck, Kroll \& Sunderman 2009). On practical level, it has been shown that the $\mathrm{L} 1$ request behavior drives the L2 course from two semesters to the L2 property. In other words, low level learner L1 processing (e.g., Morphological syntax, utility language) has shown that it is affected after a longer period of L2 exposure/experience. According to Flege and Schmidt (1995), more experience with L2 will result in a greater impact of L2 on L1. Other researchers also suggested that L2 learning could lead to the reconstruction of shared L1-L2 acoustic speech and pragmatic spaces, leading to deviations of the monolingual specification of the L1 category (Leather \& James, 1996). Production - The problem of perceived interaction is related to whether the actual speech production or auditory exposure (i.e., perception) is required to make L1 production change. At least one study showed that only exposure

Table 3. Paired-samples $t$-test for pragmatic transfer in L1

\begin{tabular}{|c|c|c|c|c|c|c|c|}
\hline \multicolumn{5}{|c|}{ Paired Differences } & \multirow[t]{3}{*}{$t$} & \multirow[t]{3}{*}{ df } & \multirow[t]{3}{*}{$p$} \\
\hline \multirow[t]{2}{*}{$M$} & \multirow[t]{2}{*}{$S D$} & \multirow[t]{2}{*}{$\begin{array}{l}\text { Std. Error } \\
\text { Mean }\end{array}$} & \multicolumn{2}{|c|}{$\begin{array}{l}\text { 95\% Confidence } \\
\text { Interval of the } \\
\text { Difference }\end{array}$} & & & \\
\hline & & & Lower & Upper & & & \\
\hline 2 & 1.763 & 0.557 & 0.738 & 3.261 & 3.58 & 9 & 0.006 \\
\hline
\end{tabular}

to L2 did not lead to bias in L1 speech, which indicates that L2 production is required for L1 production changes (Fowler, Sramko, Ostry, Rowland, \& Halle, 2008). Later second language acquisition can lead to the reorganization of the L1 pragmatic space compared to the very early bilingual. For example, early Persians teach English between the ages 5 and 7 - English bilingual people indicate that their L1 request behavior has changed. Flege and Schmidt (1995) claim that L2 efficacy has been shown to influence the extent to which L1 speech is influenced by L2 properties. In particular, it appears that when L2 is not valid, L1 speech production is not changed and is still close to the monolingual specification. According to Tice and Woodley (2012), the findings of the L2 learning phase indicate that (1) drift can be the largest at the beginning of L2 learning, partly due to new effects, which prove that L1 is dynamic and that plastic systems are susceptible up to L2's very limited experience, (2) At L2's later stage, the drift of the L1 category is reduced, but (2) in later stages of L2 mastery it is usually associated with L1 loss, and the L1 category is re-oriented to or away from the L2 type, which is now the dominant and most used category.

\section{CONCLUSION}

It has been determined that the generation of the second language speech act (i.e. the request strategy) is affected by L1. There are more and more literatures revised in this paper, indicating that after learning a second language, pragmatic production (or behavioral behavior) will also change. The nature, extent and presence of such L1 modifications depend to a large extent on factors such as age, efficiency, learning, immersion and the quantity and quality of L1 and L2. In addition, driving can be observed after a short period of speech behavior training or after long-term learning and consolidation of the second language. In summary, the literature indicates that both L1 and L2 are plastic and may change at any age. Our review also shows that the way in which a particular factor modulates the effect of L2 on L1 is not necessarily the linearity of the time function. Further research is needed to better explain the mechanisms and temporal dynamics of these bilingual speech interactions using controlled laboratory studies. This study shows that the longer the retention time in L2, the greater the benefit of L1. In a previous study Swain and Lapkin (1982) showed that teaching provided the best results for learners' L1, while Lambert and Tucker (1972) found that learners needed more instruction in order to learn a second language. As with previous studies, this study found that participants' L1 is often positively affected by L2 learning. As described

Table 4. Paired-samples $t$-test for pragmatic transfer in L2

\begin{tabular}{|c|c|c|c|c|c|c|c|c|c|c|c|}
\hline \multirow{2}{*}{\multicolumn{2}{|c|}{ Pre L2 }} & \multirow{2}{*}{\multicolumn{2}{|c|}{ Post L2 }} & \multicolumn{5}{|c|}{ Paired Differences } & \multirow[t]{3}{*}{$t$} & \multirow[t]{3}{*}{ df } & \multirow[t]{3}{*}{$p$} \\
\hline & & & & \multirow[t]{2}{*}{$\begin{array}{l}\text { Mean } \\
\text { Difference M }\end{array}$} & \multirow[t]{2}{*}{$S D$} & \multirow[t]{2}{*}{$\begin{array}{l}\text { Std. Error } \\
\text { Mean }\end{array}$} & \multicolumn{2}{|c|}{$\begin{array}{l}95 \% \text { Confidence Interval } \\
\text { of the Difference }\end{array}$} & & & \\
\hline$M$ & $S D$ & $M$ & $S D$ & & & & Lower & Upper & & & \\
\hline 2.2 & 0.42 & 5.2 & 1.22 & -3 & 1.49 & 0.47 & -4.06 & -1.93 & -6.36 & 9 & 0.001 \\
\hline
\end{tabular}


by Folse (2004), language conversion between English and Persian is possible because both languages belong to the same Indo-European language family. The results show that L2 students have experienced these benefits in L1. Although it is hard to say to what degree this positive impact is the outcome of second-language research, it is more relevant to these children than children who are not bilingual. The relationship between the two factors of children's intelligence and effect level can be used as an area to consider in subsequent research.

This paper investigated the transfer of second language to the first language by studying the influence of the English request speech act on Persian requestive acts. The results showed that there was a backward transfer. However, the potential for reverse transmission is not unconditional. Backward transfer is closely related to the second language or foreign language level of ESL/EFL students. Only when the second language or foreign language level of ESL/EFL students does not reach the "critical threshold", they will convert the second language structure into their native language. The second language proficiency of L2 subjects has not yet reached the "critical threshold", so it's easy to move backwards. Their English proficiency is far above the critical threshold, and they can treat the two language systems differently and use them alternately. When a backward transfer occurs, the native language of ESL/EFL students will display certain features of their second language. This study was conducted in the native language of second language users, confirming Cook's different skill theory. This research is of great importance in teaching. The focus of second language teaching has always been to teach students to be as native as they are. Therefore, it is generally recommended that ESL students follow native English speakers in language use and disposition. However, as Cook (2003) said, two-language learners have their own unique characteristics: their bilingual knowledge differs from mother tongue speakers, and their mother tongue knowledge differs from mother tongue-linguistic knowledge. Due to the fact that the two language systems interact in the single thought of a second language learner, he or she is a person in itself, not an imitation of others (Cook, 2003, p. 4). Therefore, the purpose of second language teaching or learning is not to encourage students to mimic and transmit to native speakers. Instead, teachers must strive to make students aware of the similarities and differences between their mother tongue and second language to help them become multi-capacity owners that vary between the two language systems. In addition, ESL/EFL students must improve their mother tongue level, except that they spend most of their time to improve their second language level. In this way, they can improve their ability to use a second or foreign language without using the first language.

There are limitations in this study. First, the age, education and length of subjects are controlled. In other words, EFL learners are pre-school children between the ages of 4 and 6 . Therefore, the summary and conclusions will only apply to people with similar characteristics. There may be other cognitive and practical benefits, but it has not been tested in this study.

\section{REFERENCES}

Albirini, A., \& Benmamoun, E. (2014). Aspects of second language transfer in the oral production of Egyptian and Palestinian heritage speakers. International Journal of Bilingualism, 18(3), 244-273. http://dx.doi. org/10.1177/1367006912441729.

Austin, J. L. (1962). How to do things with words. Oxford: Oxford University Press.

Bardovi-Harlig, K. (2001). Evaluating the empirical evidence: grounds for instruction in pragmatics. In K. R. Rose \& G. Kasper (Eds.), Pragmatics in Language Teaching,13-32. Cambridge: Cambridge University Press.

Barron, A. (2003). Acquisition in interlanguage pragmatics: Learning how to do things with words in a study abroad context. Amsterdam: John Benjamin's.

Beebe, L. M., Takahashi, T., \& Uliss-Weltz, R. (1990). Pragmatic transfer in ESL refusals. In R. C. Scarcella, E. S. Andersen \& S. D. Krashen (Eds.), Developing communicative competence in a second language, 5573. New York: Newbury House.

Bialystok, E. (1993). Symbolic representation and attentional control in pragmatic competence. In G. Kasper and S. Blum-Kulka (Eds.), Interlanguage Pragmatics,43-57. New York: Oxford University Press.

Bloom, B.S. (1964). Stability and Change in Human Characteristics. New York: Wiley.

Blum-Kulka, S., \& Olshtain, E. (1984). Requests and Apologies: A Cross-Cultural Study of Speech Act Realization Patterns (CCSARP). Applied Linguistics, 5(3), 196-213. http://dx.doi.org/10.1093/applin/5.3.196.

Blum-Kulka, S. (1991). Interlanguage Pragmatics: The case of requests. In Phillipson, R. et al. (Eds.) Foreign/second language pedagogy research, 255-272. Clevedon: Multilingual Matters Ltd.

Blum-Kulka, S., House, J. \& Kasper, G. (1989). Investigating cross-cultural pragmatics: an introductory overview. In Blum-Kulka, J. House, and G. Kasper (eds.), Cross-cultural Pragmatics: Requests and Apologies, S (p. 136). Norwood, NJ: Ablex.

Brown, P., \& Levinson, S. C. (1987). Politeness: Some universals in language usage. Cambridge, UK: Cambridge University Press.Buzan, T. (1984). Use your memory. London: Guild Publishing.

Byon, A. S. (2004). Sociopragmatic analysis of Korean requests: Pedagogical setting. Journal of

Pragmatics 36, 1973-1704.

Cook, V. J. (Ed.). (2003). Effects of the second language on the first. Clevedon: Multilingual Matters Ltd.

Diamond, M.C. (1988). Enriching Heredity: The Impact of the Environment on the Anatomy of the Brain. LA: University of California, Free Press.

Dryden, G., \& Vos, J. (1997). The Learning Revolution. Auckland, NZ: The Learning Web.

Eslami, Z., \& Eslami-Rasekh, A. (2008). Enhancing the pragmatic competence of non-native English-speaking Teacher Candidates (NNESTCs) in an EFL context. In E. Alcon Soler \& A. Martinez-Flor (Eds.), Investigat- 
ing pragmatics in foreign language learning, 178-197. Bristol: Multilingual Matters.

Eslami-Rasekh, A., \& Abdolnazarpour, P. (2010). A cross-cultural study of perception of politeness by Iranian and American in request forms. Pakistan Journal of Social Science, 7(2), 164-169.

Ellis, R. (1994). The study of second language acquisition. Oxford, UK: Oxford University Press.

Flege, J. E., \& Schmidt, A. M. (1995). Native speakers of Spanish show rate-dependent processing of English stop consonants. Phonetica, 52(2), 90-111.

Folse, K. S. (2004). Vocabulary myths: Applying second language research to classroom teaching. Ann Arbor: University of Michigan Press.

Fowler, C. A., Sramko, V., Ostry, D. J., Rowland, S. A., \& Hallé, P. (2008). Cross language phonetic influences on the speech of French-English bilinguals. Journal of Phonetics, 36(4), 649-663.

Fukushima, S. (2002). Requests and culture: Politeness in British English and Japanese. Switzerland: Peter Lang AG.

Goffman, E. (2006). On face-work: An analysis of ritual elements in social interaction. In A. Jaworski \& N. Coupland (Eds.), The discourse reader, 299-310. New York: Routledge.

Gass \& Selinker, L. (2008). Second Language Acquisition: An introductory course ( $3^{\text {rd }}$ ed.). New York, NY: Routledge.

Hymes, D. (1974). Foundations in Sociolinguistics: An Ethnographic Approach. The University of Pennsylvania Press, Inc. Cinnaminson, NJ. Retrieved from http:// www1.appstate.edu/ mcgowant/hymes.htm.

House, J., \& Kasper, G. (1981). Politeness markers in English and German. In: F. Coulmas (Ed.), Conversational Routine, 157-185. The Netherlands: Mouton de Gruyter.

Kasper, L. F. (1993). The keyword method and foreign language vocabulary learning: A rationale for its use. Foreign Language Annals, 26(2), 244-251.

Kasper, G. (2002). Conversation analysis as an approach to second language acquisition: Old wine in new bottles. Invited talk, SLATE speaker series, University of Illinois at Urbana-Champaign.

Kecskes, I. (2008). Dueling contexts: A dynamic model of meaning. Journal of Pragmatics, 40(3), 385-406.

Kesckes, I., \& Papp, T. (2000). Foreign Language and Mother Tongue, Erlbaum Press.

Keshavarz, M. H., Eslami, Z. R., \& Ghahreman, V. (2006). Pragmatic Transfer and Iranian EFL Refusals: A Cross-Cultural Perspective of Persian and English. K. Bardovi-Harlig, J. C. Félix-Brasdefer \& A. Omar (Eds.), Pragmatics and Language Learning V. 11,359403. Manoah, HI: Second Language Teaching and Curriculum Center University of Hawai'i.

Kolb, D. (1984). Experiential learning. Experience as the source of learning and development. Englewood Cliffs, New Jersey: Prentice Hall.

Lambert, W. E., \& Tucker, G. R. (1972). Bilingual education of children: The St. Lambert experiment.

Leather, J., \& James, A. (1996). Second language speech. Handbook of second language acquisition, London: Routledge.
Leech, G. (1983). Principles of pragmatics. London and New York: Longman.

Linck, J. A., Kroll, J. F., \& Sunderman, G. (2009). Losing access to the native language while immersed in a second language: Evidence for the role of inhibition in second-language learning. Psychological science, 20(12), 1507-1515.

Liu, S. (2007). What is pragmatics? Retrieved from: http:// www.gxnu.edu.cn/Personal/szliu/definition.html.

Olshtain, E., \& Blum-Kulka, S. (1985). Degree of approximation: Nonnative reactions to native speech act behavior. In: S. Gass, \& C. Madden (Eds.), Input in Second Language Acquisition,303-325. Rowley: Newbury House.

Olshtain, E., \& Cohen, A. (1990). The learning of complex speech act behavior. TESL Canada Journal, 7(2), 45-65. doi:10.18806/TESL. v7i2.568.

Ornstein, E.R. (1984). The Amazing Brain. New York: Houghton Mifflin Harcourt.

Salazar, P. (2003). Pragmatic instruction in the EFL context. In: A. Martinez-Flor, E. Uso-Juan, \& A. Fernandez-Guerra (Eds.), Pragmatic Competence and Foreign Language Teaching, 233-246. Castello: Publicacions de la Universitat Jaume I.

Schmidt, R. (1993). Consciousness, learning and Interlanguage pragmatics. In: G. Kasper \& S. Blum-Kulka (Eds.), Interlanguage Pragmatics,21-42. New York: Oxford University Press.

Searle, J. R. (1969). Speech Acts: An essay in the philosophy of language. Cambridge, UK: Cambridge University Press.

Searle, J. R. (1976). Indirect speech acts. In P. Cole \& J. Morgan (Eds.), Syntax and semantics 3; Speech Acts, 59-82. New York: Academic Press.

Swain, M., \& Lapkin, S. (1982). Evaluating Bilingual Education: A Canadian Case Study. Multilingual Matters 2. Toronto: Ontario Inst. for Studies in Education.

Takahashi, S. (1993). Transferability of L1 indirect request strategies to L2 contexts. In L. F. Bouton \& Y. Kachru (Eds.), Pragmatics and Language Learning, monograph series, 4,50-84). Urbana Champaign, IL: Division of English as an International Language, University of Illinois, Urbana Champaign.

Takahashi, S. (1996). Pragmatic transferability. Studies in Second Language Acquisition, 18, 189-223.

Takahashi, S., \& DuFon, M. A. (1989). Cross-linguistic influence in indirectness: The case of English directives performed by native Japanese speakers. Unpublished manuscript, Department of English as a Second Language, University of Hawai'i at Manoah. (ERIC Document Reproduction Service No. ED370439).

Thomas, J. (1983). Cross-cultural pragmatic failure. Applied Linguistics, 4(2), 91-122.

Tice, M., \& Woodley, M. (2012). Paguettes \& bastries: Novice French learners show shifts in native phoneme boundaries. UC Berkeley PhonLab Annual Report, Retrieved on 22/05/2018 from https://cloudfront.escholarship.org/dist/prd/content/qt9h18t4rz/qt9h18t4rz.pdf

Wang, V. X. (2011). Making requests by Chinese EFL learners. Netherlands: John Benjamin's Publishing Co. 
Yang, L. (2009). The speech act of request: A comparative study of Chinese and American graduate students at an American university (Master's thesis). Graduate College of Bowling Green State University, OH.

Yarmohammadi, L. (1995). More on the analysis of politeness form in English and Persian: A sociopragmatic approach. IJOAL, 21(1), 57-67.

Yu, M. (2011). Culture-specific concepts of politeness: Indirectness and politeness in English. Intercultural Pragmatics, 8(3), 385-409.

Yu, M. (2011). Learning how to read situations and know what is the right thing to say or do in an L2: A study of socio-cultural competence and language transfer. Journal of Pragmatics, 43(4), 1127-1147. doi: 10.1016/j.pragma.2009.09.025.
Yule, G. (1996). Pragmatics. Oxford, UK: Oxford University Press.

Zhang, J. (1998). Improvement in classroom teaching of English. In Parry, K. (Ed.) 1998. Culture. Literacy, and Learning English: Voices from the Chinese Classroom. Portsmouth, NH. Boyton/Cook Publishers, 212-215.

Zhang, S., \& Wang, X. (1997). A comparative study of the speech act of requests. Modern Foreign Languages, 3, 63-72.

Zhang, Y. (1995). Indirectness in Chinese Requesting. In G. Kasper (Ed.), Pragmatics of Chinese as native and target language, 69-118. Hawai'i: University of Hawai'i Press. 